\title{
Modeling the impact of innovation policy on the level of development and economic security of the country
}

\author{
Mykhaylo Voynarenko \\ First Vice-Rector, Vice-Rector for \\ Scientific-Pedagogical and \\ Scientific work \\ Khmelnytsky National University \\ Khmelnytsky, Ukraine \\ voynarenko@ukr.net
}

\author{
Viktoriya Hurochkina \\ Department of Enterprise Economics \\ University of the State Fiscal Service of \\ Ukraine \\ Irpin, Ukraine \\ viktoriav2005@ukr.net \\ Olena Menchynska \\ Department of Economics and \\ International Relations \\ Vinnytsia Trade and Economic Institute \\ of KNTEU \\ Vinnytsia, Ukraine \\ derkacholena@ukr.net
}

\author{
Olena Kovalenko \\ Department of software \\ Vinnytsia National Technical \\ University \\ Vinnytsia, Ukraine \\ ok@vntu.edu.ua
}

\begin{abstract}
- article deals with results of implementation innovation policy of Ukraine, which are reflected in global ratings. Today, key innovation indices are characterized by development of inclusive development, formation digital and innovative economy, conditions of doing business and creation of innovative country infrastructure. Ukraine's place in the leading global rankings is characterized. Dynamics levels of economic security and shadow economy were studied according to the information of leading national institutions, which allowed determining the main strategic priorities of national development. Causal relationship between architecture of Ukraine's international indices and internal conditions of country's development has been determined. Basis calculations are a multi-factor correlation-regression model based on sophisticated index estimation technology. Method of determination stimulants and simulators regarding values of level economic security of Ukraine is described. System of correspondence between quantitative and qualitative values level of internal security of economic security country is presented. Results of cause-and-effect relationship make it possible to identify and concentrate on strengthening Ukraine's weaknesses.
\end{abstract}

Keywords - innovation policy, digital economy, innovative economy, economic security, modeling, multifactor correlationregression model, strategic priorities

\section{INTRODUCTION}

In era of global transformations of world's economies, the main tendency for development economic system remains the transition to an innovative and intellectually oriented type. In order to strengthen competitive positions in world arena, it is advisable for developing countries to focus on policy of intellectualization social production, which is embedded in innovative model of country's development. This will enable modernization and complete reloading of production complex for purposes of innovative economic development of country.

Effectiveness of country's innovation policy is reflected in aggregate of indices presented in global rankings. At present, the main indexes are inclusive development index
IDI, digital and innovation economy index (ICT Development Index), Doing Business Index and creation of a country's innovative infrastructure and Global Competitiveness Index.

The basis of the research is the hypothesis of the dependence of economic security on the level of implementation of the country's innovation policy, which is reflected in the state of information technology, information society, business and competitiveness, and in general to identify the existing contradictions in the impact on the level of economic security of the country. In the middle of the country, innovation policy has a significant impact on the interests of society and characterizes the level of protection of the economic system as a whole. The level of economic security of the country is formed by the security of the state, the economic security of economic entities and the security of the individual or society. Therefore, in the study of the leverage of innovation policy on the state of protection of interests of society and the level of economic security for the purposes of determining strategic development priorities, it is advisable to analyze the country's place according to the international assessment and to determine the cause and effect relationships between the above indicators. The mathematical apparatus of correlationregression analysis is used to evaluate the impact.

Correlation-regression model provides an opportunity to analyze impact of development information technology, business, competitiveness on level of economic security. Various qualitative characteristics testify to presence of two directions - positive and negative of such influence. This is especially true information technology. They, on the one hand, have a positive effect on overall development of economy and its security; on the other hand, it is a source of risk for an open information environment; transfer of sensitive information, etc.

\section{LITERATURE REVIEW}

The main obstacle to the transition to innovative development of Ukraine remains a global threat to national 
security. At present, there is a military intervention on the part of Russia, which has character of terrorist aggression and affects national integrity. Such problems are a consequence of instability in economic and political spheres of the country. As regards country's economic insecurity, it should be noted that these problems require preventive protection and ongoing economic monitoring the level of economic security and its functional components. These measures can be carried out using a mathematical apparatus of correlation-regression analysis.

The level of economic security is first and foremost influenced by development of information technology, which is object of a great deal of scientific research. Yes, research into impact of development IT on the level of economic security of country and state protection of society, for example country Bangladesh, attention is paid to the article [3]. This paper is based on the study conducted as part of IDA funded Enterprise Growth and Bank Modernization Project and explores the opportunities and barriers of using ICT to provide a necessary lever to enhance competitiveness and productivity SOEs in Bangladesh.

Today, innovations in information technology are having wide-ranging effects across numerous domain's society, and policy-makers are acting on issues involving economic productivity, intellectual property rights, privacy protection, and affordability of access to information [14]. Importance of influence technology on the economic system as a whole has been repeatedly mentioned in scientific works and also in work [15].

Authors' position is interesting L. Huang, B. Gu exploring [4]: authors investigated through analysis of problems existing in Cangzhou E-Government.

Impact of digital technology on development of the country was noted Xiaohong Xu, Hu Tian, Jilin Fu, Zhihua Sun, Xin $\mathrm{Xu}$ in article "Status and Design of Digital Oilfield" This paper expounds the difficulties that the domestic digital oilfield encountered in design of construction, and combining with the actual need of the oil fields in the development of oil-gas exploration, especially discusses the common problems in the construction of current digital oilfield and analyzes the existing oilfield technology and the development needs, finally, it put forwards feasible solutions [5].

Topical from point of view of convenience of application are correlation-regression models that provide an opportunity to determine result of the impact of economic security on economic system or state of development of country on level of economic security. So in the article Liang-Hung Lin [8] the fuzzy regression is determined as predicting nonlinear variables best method.

In Article G. Okpali, T. Uchegbu, S. Okide [13] researchers adopted descriptive method in analysis of data using tables and simple percentages and chi-square. Primary source of data was from respondents administered questionnaire of a sample size 80 .

Considering the considerable achievements, the causal link between the main indicators of the country's development and the level of economic security remains, which determined the direction of scientific research.

\section{PROBLEM DESCRIPTION AND METHODOLOGY}

Methodology of the study is to identify and analyze various economic security indices and subindices, development indices of Ukraine in world rankings and identify the impact of their dynamic changes. The mathematical apparatus of correlation-regression analysis allows to form conclusions about the presence of such influence. Correlation analysis solves two problems:

1) determining the form of the relationship, that is, establishing a mathematical formula that describes the relationship;

2) measurement of communication density.

In simplest case, the relationship between two metrics is examined, one of which is considered as an independent metric - a factor ( $\mathrm{x}$ ) and other as a dependent variable, productive sign (y). This is the so-called "pair correlation". In general, it is described by the function $\mathrm{y}=f(\mathrm{x})$.

Mathematical function is predetermined by qualitative analysis of relationship between phenomena and their graphical representation in the form of a correlation field.

Along with correlation coefficient, another criterion is also used to measure the link density between two or more indicators and to check the adequacy (fit) of the constructed regression model for reality. That is, answer to the question is whether the change in value depends linearly on change in the value of $\mathrm{x}$, and does not occur under influence of various random factors. This criterion is coefficient of determination.

Hypothesis of study is that level of economic security of country depends on the level of development information technologies, access to data and knowledge, state of information society, business development and competitiveness. All identified areas contain contradictions in influencing level of economic security of country. In an ideal model, negative and positive factors impact of these areas on the level of economic security should be monitored by state. Negative effects are neutralized by special mechanisms, and positive ones are investigated for their further development. Study of mathematical dependencies of changes will allow identifying dependencies and to draw conclusions on improvement methodology of collecting, monitoring and processing of statistical data development of innovation policy and economic security.

\section{RESULTS AND DISCUSSIONS}

A decisive indicator of the effectiveness of a country's innovation policy is its place in global rankings. Innovative policy by its goals manifests itself in results of scientific and technological development and research, improves professional competences, provides easy access to information resources and knowledge, and all these components directly affect the level of country security, which is reflected in level of country economic security country. 
The level of economic security of the country is a complex indicator that is formed under the influence of functioning of public spheres of national security of Ukraine. According to the Ministry of Economic Development and Trade of Ukraine, 9 weighted average sub-indices, such as: production; demographic; energy; foreign economic; investment and innovation; macroeconomic; food; social; financially.

With regard to the level of development of digital economy in countries of the world, it is given much attention, as it is driver of industrialization and development of information society. International Telecommunication Union (International Telecommunication Union, ITU) generates an index rating ICT Development Index, which characterizes the level of development of information and communication technologies in different countries of the world.

Rating Doing Business - characterizes the fundamental factors of business climate. Position of each country in ranking of favorable conditions for doing business is determined by ordering of aggregate score obtained by a country in terms of distance from frontier in ten directions.

The basis The Global Competitiveness Index, GCI 98 parameters have been set, taking into account 12 groups of indicators by three main sub index groups: "Essential requirements", "Productivity enhancers", "Innovation and improvement factors".

Obtained results (Table 1) allow drawing conclusions about linear relationship between index of development of information and communication technologies and index of security. Such a linear dependence is presented in Figure 1. Linear dependence should characterize the direct relationship between defined indices. Similarly, a dependency can be constructed for the Global Competitiveness and Business Development Index. But calculation of correlation function indicates that there are no links between defined.

TABLE I. DYNAMICS OF UKRAINE DEVELOPMENT INDICATORS IN WORLD RATINGS

\begin{tabular}{|c|c|c|c|c|c|c|c|c|c|c|c|}
\hline \multirow{2}{*}{ Indicator } & \multicolumn{11}{|c|}{ Years (2007-2017) } \\
\hline & 07 & 08 & 09 & 10 & 11 & 12 & 13 & 14 & 15 & 16 & 17 \\
\hline $\begin{array}{l}\text { The level of economic } \\
\text { security }\end{array}$ & 52 & 48 & 46 & 47 & 50 & 47 & 48 & 45 & 44 & 48 & 48 \\
\hline $\begin{array}{l}\text { ICT Development } \\
\text { Index }\end{array}$ & 58 & 58 & 51 & 69 & 67 & 68 & 71 & 73 & 76 & 76 & 79 \\
\hline Doing Business Index & 128 & 144 & 145 & 146 & 147 & 149 & 137 & 112 & 96 & 83 & 80 \\
\hline $\begin{array}{l}\text { The Global } \\
\text { Competitiveness Index }\end{array}$ & 73 & 72 & 82 & 89 & 82 & 73 & 84 & 76 & 79 & 85 & 81 \\
\hline
\end{tabular}

Further study of dynamic changes according to the indexes of economic security, development of information technologies, business and competitiveness allowed to form comparative trend dependencies on Figure 2.

The results obtained formally indicate that there is no link between the indices identified. But the qualitative characteristics of business development, competitiveness, information technology indicate that this is not the case.

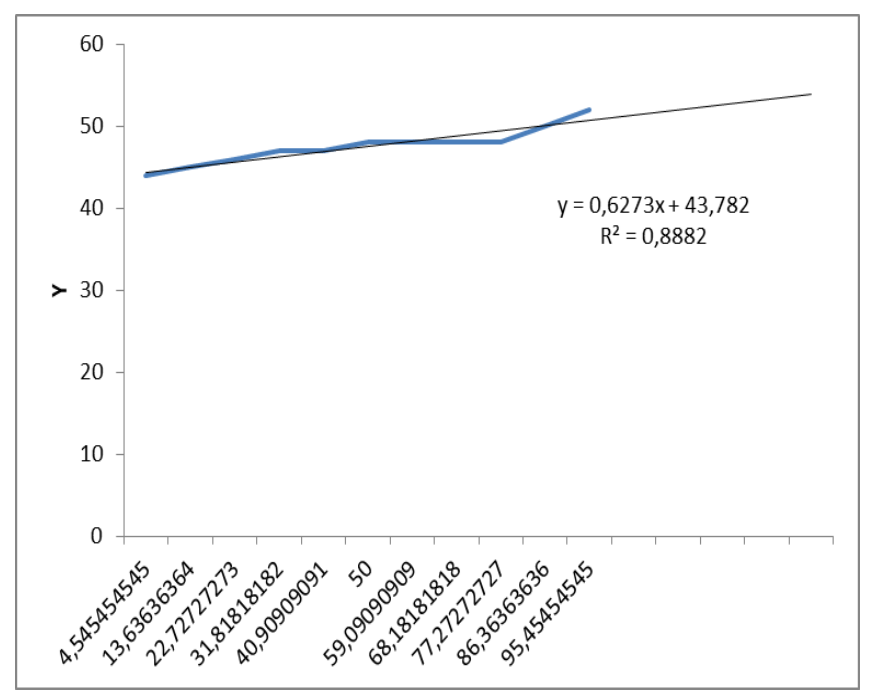

Fig. 1. Dependence between information technology development and economic security level. Source: built by the authors [21]

Table 2 presents the trend dependencies and the coefficients of determination and correlation with the level of economic security.

According to the authors, the complex dependencies of the dynamics of index changes, analysis of the qualitative characteristics of each of the areas of development of innovation policy and economic security require further research for changes in the collection and monitoring of data, detailing sub-indices in each area.

\section{CONCLUSIONS}

With regard to the level of development of digital economy in countries of world, it is given much attention, as it is the driver of industrialization and development of information society. But such developments are also a driver for increasing the risks of economic security decline. A comprehensive approach to development of innovative technologies in Ukraine and maintenance of a sufficient level of economic security should require research on neutralization of economic security risks caused by processes of digitalization and activation of global integration processes.

In order to further improve the mechanism of maintaining a sufficient level of economic security in conditions of development innovative technologies, economic security must be considered as a state of economic system in which the risk of negative consequences is neutralized with certain probability. That is, mechanism for managing the level of economic security should be based on reliable data on development of new technologies, introduction of various digital technologies for moving assets, implementation of business processes, etc.

State of economic security of country in conditions of digitalization should take into account impact of development and introduction of innovative technologies at all economic levels from entrepreneur to state and international partnership. 


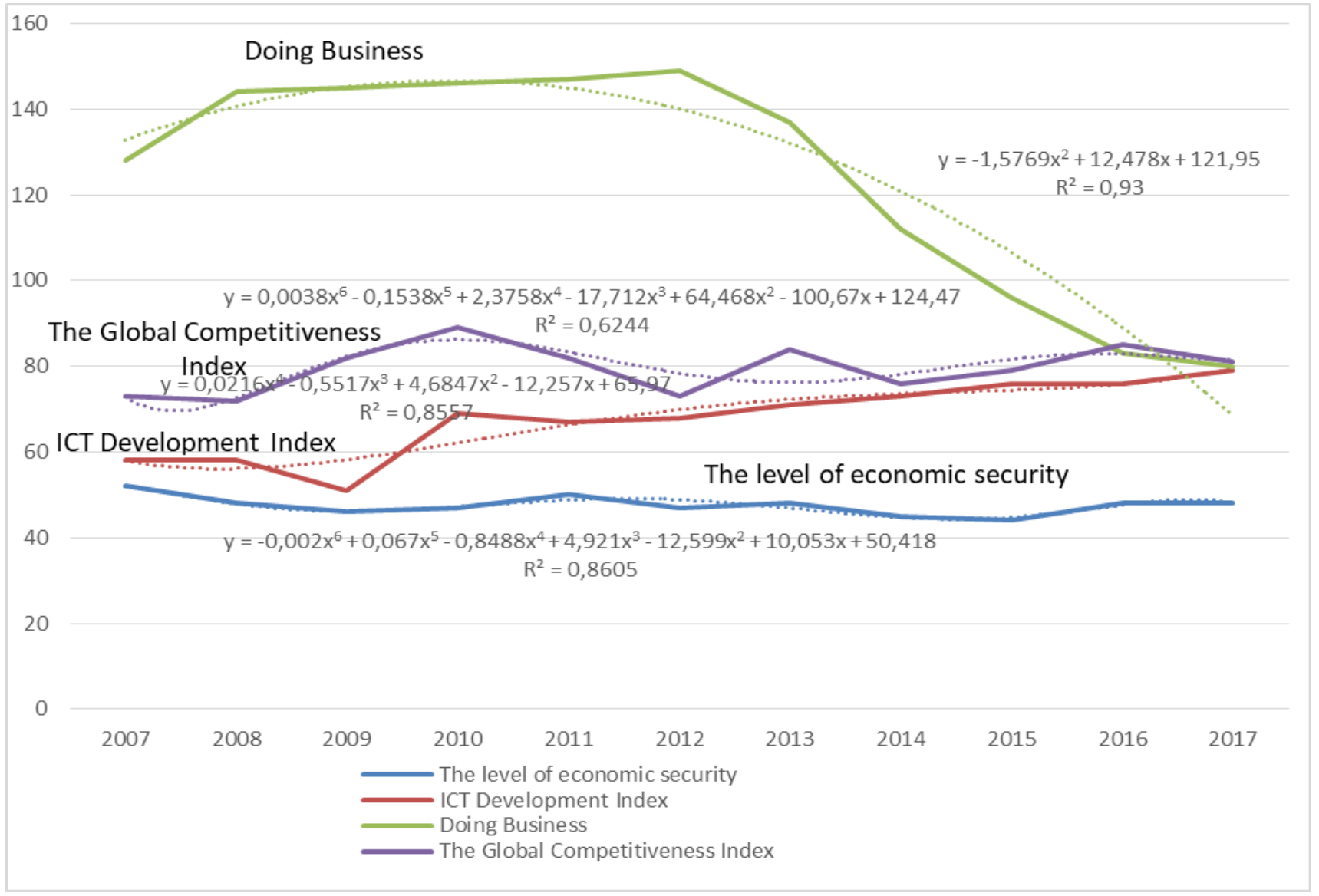

Fig. 2. Trend dependencies of dynamic changes in Ukraine's development indicators in world rankings. Source: built by the authors [20][21][22]

TABLE II. TREND DEPENDENCIES AND COEFFICIENTS OF DETERMINATION AND CORRELATION WITH THE LEVEL OF ECONOMIC SECURITY

\begin{tabular}{|l|c|c|c|}
\hline \multicolumn{1}{|c|}{ Indicator } & Formula & $\begin{array}{c}\text { R2 } \\
\text { coefficient of } \\
\text { determination }\end{array}$ & $\begin{array}{c}\text { K } \\
\text { Correlation coefficient } \\
\text { with the level of } \\
\text { economic security }\end{array}$ \\
\hline The level of economic security & $\mathrm{y}=-0,002 \mathrm{x}^{6}+0,067 \mathrm{x}^{5}-0,8488 \mathrm{x}^{4}+4,921 \mathrm{x}^{3}-12,599 \mathrm{x}^{2}+$ & 0,86 & - \\
\hline ICT Development Index & $\mathrm{y}=0,0216 \mathrm{x}^{4}-0,5517 \mathrm{x}^{3}+4,6847 \mathrm{x}^{2}-12,257 \mathrm{x}+65,97$ & 0,86 & $-0,129$ \\
\hline Doing Business Index & $\mathrm{y}=-1,5769 \mathrm{x}^{2}+12,478 \mathrm{x}+121,95$ & 0,93 & 0,26 \\
\hline The Global Competitiveness Index & $\mathrm{y}=0,0038 \mathrm{x}^{6}-0,1538 \mathrm{x}^{5}+2,3758 \mathrm{x}^{4}-17,712 \mathrm{x}^{3}+64,468 \mathrm{x}^{2}-$ & 0,63 & $-0,29$ \\
\hline
\end{tabular}

Source: calculated by authors [20][21][22]

Equal partnership in field of information technology development with international vendor enterprises; ensuring protection of domestic products and services of intellectual value. Methodology for evaluating economic security indices and sub-indices, business development and innovative technologies should take into account international experience.

Mechanism for introducing an improved methodology should provide for changes in processes for collecting, monitoring, processing and reporting statistics. To assess the level of economic security, it is advisable to use an indicator, resource-functional and program-targeted approach that will allow identifying groups of economic security indicators - stimulants and simulators.
Balance of macroeconomic reproductive proportions is the basis of economic security. The logic of the development of innovative technologies, in particular digital, business, competitiveness should be shaped by a hierarchy of achieving high economic results both in national economy and in introduction of digital technologies. But risks of information inequality of countries - international partners; reducing barriers to information and payment flows have a negative impact on economic security. All identified contradictions and risks can be reduced by introducing improvements in methodologies for determining and monitoring the level of economic security and other national economic development indices. Innovative security is the state's ability to generate progressive shifts in technology, technology, labor, 
information, and goods. Business development and competitiveness are not possible without support of both innovative and economic security.

This indicates that the indicators of such development must be reliable. In this case, they will become a tool for managing the country's economic security risks.

\section{ACKNOWLEDGMENT}

The work was carried out within the framework of the state budget scientific research topic number 7B-2016 "Models and technologies of cluster formation in the strategies of institutional development of socio-economic systems" (2016-2018 years), for financing the Ministry of Education and Science of Ukraine (state registration number 0116U001551).

\section{REFERENCES}

1] A. Asaul, M. Voynarenko, L. Dzhulii, L .Yemchuk, L. Skorobohata, and O. Mykoliuk, "The latest information systems in the enterprise management and trends in their development", The 9th International Conference Advanced computer information technologies (ACIT 2019), IEEE, Ceske Budejovice, Czech Republic, August 2019, pp. 362-365. Doi: 10.1109/ACITT.2019.8779874.

[2] M. Voynarenko, K. Dumanska, and N. Ponomaryova, "Formation of company's economic activity context in the strategic positioning process in emergent environment conditions", The 8th International Conference on Monitoring, Modeling \& Management of Emergent Economy, EDP Sciences, vol. 65, pp. 1-7, May 2019. Doi: https://doi.org/10.1051/shsconf/20196504005

[3] A. M. Dewan, S. M. Dewan, and S. A. Nazmin, "Use of Information and Communication Technology by State Owned Enterprises in Bangladesh: Comparison between privatized and non privatized SOEs", The International Technology Management Review, vol. 2 (1), pp. 19-32, October $2009 . \quad$ Doi: https://doi.org/10.2991/itmr.2009.2.1.2

[4] L. Huang, and B. Gu "Resource-sharing Construction of Area Egovernment Information Based on Cloud-computing" Proceedings of the 2nd International Conference on Computer Science and Electronics Engineering (ICCSEE 2013), Atlantis Press, Paris, France, March 2013. Doi: https://doi.org/10.2991/iccsee.2013.4

[5] X. Xu, H. Tian, J. Fu, Z. Sun, and X. Xu, "Status and Design of Digital Oilfield", Proceedings of the 2nd International Conference on Computer Science and Electronics Engineering (ICCSEE 2013), Atlantis Press, Paris, France, March 2013. Doi: https://doi.org/10.2991/iccsee.2013.11

[6] L. Zhao, and Y. Zi, "The Network Security Management Problem of Library", Proceedings of the 2nd International Conference on Computer Science and Electronics Engineering (ICCSEE 2013), Atlantis Press, Paris, France, March 2013. Doi: https://doi.org/10.2991/iccsee.2013.746

[7] J. Edler, and J. Fagerberg, "Innovation policy: What, why, and how" Oxford Review of Economic Policy, vol. 33 (1), pp. 2-23, 2017. Doi: https://doi.org/10.1093/oxrep/grx001.

[8] L.-H. Lin "Using Fuzzy Regression and Neural Network to Predict Organizational Performance", 9th Joint International Conference on Information Sciences (JCIS-06), Atlantis Press, October 2006. Doi: https://doi.org/10.2991/jcis.2006.137
[9] M. Graham, "Digital Economies at Global Margins", The MIT Press, London, England, $2019 . \quad$ [Online]. Available: https://www.idrc.ca/sites/default/files/sp/Images/idl-57429_2.pdf

[10] L. Smoliy, A. Revutska, and I. Novak, "Influence of innovation factor in economic dynamics in europe", Marketing and Management Innovation, vol. 1, pp. 247-258, 2018. Doi: 10.21272/mmi.2018.1-18

[11] Fostering Innovation: The Policy Challenge, The OECD innovation strategy: getting a head start on tomorrow, OECD, 2010. [Online]. Available: https://www.oecd.org/berlin/45331377.pdf

[12] J. Edler, P. Cunningham, A. Gök, and P. Shapira, "Impacts of Innovation Policy: Synthesis and Conclusion”, Nesta Working Paper, vol. 13 (21), November 2013. [Online]. Available: https://media.nesta.org.uk/documents/impacts_of_innovation_policy_ synthesis_and_conclusion_final.pdf

[13] G. Okpali, T. Uchegbu, and S. Okide, "Promoting Economic Security through Information Technology", West African Journal of Industrial and Academic Research, vol. 9 (1), Decemder 2013. [Online]. Available:https://www.ajol.info/index.php/wajiar/article/view/105729

[14] R. K. Lee, "Impacts of information technology on society in the new century", Route de Chavannes, August 2009. [Online]. Available: https://www.zurich.ibm.com/pdf/news/Konsbruck.pdf

[15] B. B. Hughes, D. Bohl, M. Irfan, E. Margolese-Malin, and J.R. Solórzano, "ICT/Cyber benefits and costs: Reconciling competing perspectives on the current and future balance", Technological Forecasting \& Social Change, July 2016. [Online]. Available http://isiarticles.com/bundles/Article/pre/pdf/124663.pdf

[16] V. Hryhorkiv, L. Buiak, A. Verstiak, M. Hryhorkiv, and O. Savko, "Enterprise application software implementation at the enterprise of wood processing industry : case study", International Journal of Computing, vol. 16 (4), pp. 265-268, 2017

[17] L. I. Fedulova, "Conceptual bases of management of innovative development of enterprises", Marketing and Management of Innovation, vol. 2, pp. 122-135, 2014.

[18] O. I. Gonchar, "Scientific and methodical bases of perfection enterprise capacity assessment", Scientific bulletin of Polissia, vol. 1(9), pp. 134-139, 2017. [Online]. Available: https://nvp.stu.cn.ua/en/component/k2/item/673-gonchar-o-iscientific-and-methodical-bases-of-perfection-enterprise-capacityassessment.html

[19] A. Shtangret, N. Melnyk, I. Shevchuk, and T. Shyra, "Information Support for the Management of the Economic Security of High-Tech Enterprises", The 9th International Conference Advanced computer information technologies (ACIT'2019), IEEE, Ceske Budejovice, Czech Republic, August 2019, pp. 350-353. Doi: 10.1109/ACITT.2019.8779922

[20] Doing Business Reports, The World Bank, 2017. [Online]. Available: https://www.doingbusiness.org/en/reports/global-reports/doingbusiness-2017

[21] ICT Development Index, International Telecommunication Union, 2017. [Online]. Available: https://www.itu.int/net4/ITUD/idi/2017/index.html

[22] The Global Competitiveness Index, World Economic Forum, 2017. [Online]. Available: http://www3.weforum.org/docs/GCR20172018/05FullReport/TheGlobalCompetitivenessReport2017\%E2\%80\% 932018.pdf

[23] P. M. Hryhoruk, N. A. Khrushch, and S. S. Grygoruk, "An approach to construct fuzzy preference relationships for managerial decision making", Scientific bulletin of Polissya, vol.4(12), pp.92-99, 2017. Doi: 10.25140/2410-9576-2017-2-4(12)-92-99. [in Ukrainian] 